\title{
The Role of Human Resources Management Builds Knowledge Management in the Situation of Increasing Employees Voluntary Turnover (Case study in the Production Division of an Indonesian National Private Television Company 2019-2020)
}

\author{
Zahara Tussoleha Rony ${ }^{1}$, Suharjuddin ${ }^{2}$, Sani Aryanto ${ }^{3}$ \\ \{zahara.tussoleha@dsn.ubharajaya.ac.id ${ }^{1}$ \} \\ Magister Management, Universitas Bhayangkara University Jakarta Raya, 12250, Indonesia ${ }^{1}$ \\ Pendidikan Guru Sekolah Dasar, Universitas Bhayangkara Jakarta Raya, 12550, Indonesia ${ }^{2,3}$
}

\begin{abstract}
The high voluntary turnover of the company is a phenomenon which is commonly found in the company. It is one of serious problems causes number of qualified employees choose to leave the company. A number of company memories in the form of tacit knowledge are lost because a number of employees move to another company. The paper aims to describe the activities of human resource management (HRM) in creating a special strategy in documenting and disseminating tacit knowledge. The study uses qualitative methods for case studies, primary data is obtained from field notes and in dept interviews and observations. A sampling technique is conducted by purposive sampling and selecting 10 informants from HRM Division. In obtaining more comprehensive findings, the researcher involved 2 (two) production managers as key informant. The strategy carried out by HR managers to build a knowledge management system is not yet structured. Therefore, human resources management in that company need to design specific programs which can give added values to the company so that some knowledge can be documented and thus become assets in improving competence for employees.
\end{abstract}

Keywords: Continuous learning, knowledge management, knowledge management strategy, voluntary turnover.

\section{Introduction}

Knowledge Management (KM) is an organizational activity to manage knowledge. Knowledge is characterized as a form of asset that is compiled and developed and distributed to employees so that they interact with each other, share knowledge and apply it to work to improve organizational performance. The above facts show that knowledge management has been aligned with other resources that are equally important in influencing the company's competitive advantage. $\mathrm{KM}$ is considered a strategic resource for all types and sizes of organizations.

However, maintaining and managing assets is not an easy task, especially in the national private television company $\mathrm{X}$ which has 1,200 employees. In the past year, 2018-2019, there was a 10 percent increase in the number of employees who resigned in 3 positions, namely cameraman, editor and content creator. Lately, many young people are trying their luck, especially artists opening a business to become a YouTuber. This business is a new field for 
young people, especially those who have a spirit of creativity, entertaining and high fighting power. For an artist who deals in the world of presenter and entertainment, this business is a promising business. They need cameraman, editor and content creator. Artists easily contact television employees they known. For television employees, especially cameramen, editors and content creators, offers to work at well-known artist's company are an opportunity to get new experiences in developing creativity, especially since there is a higher amount of compensation available and more flexible working hours offered differently from previous company. The heads of this private television company felt that the ideas that had been proposed were lost with the layoff of employees. The high employee turnover rate can cause the company to lose costs [1]. The turnover phenomenon makes HRM Division do a strategy so that productivity in the company does not decrease.

It is not easy to change employees as needed at once, when employees who have worked for at least 2 or 3 years leave, new employees work for a few months who are left still filled with worries about continuing a good program. They need assistance in strengthening the existence of old programs and creating new programs. They have not had the chance to learn many things from their seniors, they have not done and shared documentation of the knowledge obtained from training, seminars and workshops attended by employees, the senior has already resigned. Voluntary turnover at television media company is a challenge for company to create an effective knowledge management strategy.

This event is important to research and explain related to the strategy of the HRM division and leaders in the production division to manage knowledge management in employee turnover situations. There are quite a lot of writings on this theme in the world of research, but they explain different themes. Some of the previous studies include Empowering leadership in management teams: Effects on knowledge sharing, efficacy, and performance and Why Knowledge Management Is Important to the Success of Your Company describes the importance of knowledge management (KM) and the building process [2][3].

This paper also describes the collaboration of the HRM division and leaders in building sustainable learning and managing knowledge management. In this research, the researcher explains the management of knowledge management from the perspective of sub-themes, on the job training, job crafting, job shadowing, regular meetings, socialization of facts. The results of this study show that the HRM division manages knowledge management quite well in creating knowledge, using knowledge and sharing knowledge, but unfortunately does not have a knowledge management system that is integrated and structured, especially in maximizing technology in documentation.

\section{Method}

Qualitative methods with the case study approach is the preferred approach to explain an event in one of the production divisions of a media company private $\mathrm{x}$ related to how the strategy HRM Division in building knowledge management in the company in a constant turnover condition [4].

A total of 10 people were assigned to be informants and 2 key informants. They were selected by purposive sampling and snowball sampling. The HRM division was chosen to be the main informant because they knew and carried out the strategy to build knowledge management, while the 2 key informants in production were people who were involved in helping human resource managers build knowledge management. At the beginning the 
researcher determined 8 main informants, but some information related to the internal information system needed to be clarified so that the researcher needed to add 2 informants. And for the 10th informant, all the information is sufficient, especially there are 2 key informants who provide additional information to clarify the information needed.

The research step begins by observing activities related to knowledge management, paying attention to on-the-job training, socialization and evaluation conducted by supervisors. During the search for initial data in the field, the researcher recorded information and gave questions to both the HR manager and several employees who were participating in the activity. During the process of obtaining data in the field the researcher continuously triangulates, if there is data that does not match between the results of the observation and the initial interview, the researcher asks, taking notes and collecting notes into questions that will be asked during the interview to the next informant. An interview guide was prepared to help researchers' direct informants to be more productive and involved in group discussions [5]. Researchers used interview guidelines that contained general questions and, in the field, developed them into specific questions [6].

To obtain this information the researcher interviewed 10 members of the human resource management and 2 heads of departments in the production division and analyzed the results of the documentation study. Researchers clarify until things that are less clear can be well confirmed. After the data is collected, transcripts are made and continued with data reduction with the process of selecting and focusing attention on simplifying and coding the data by sorting thematically represented and divided into small units (phrases, sentences, or paragraphs), the units are grouped into code [7] and create memos [8]. The findings were discussed with all informants and key informants in a focus group discussion.

\section{Results and Discussion}

\subsection{Results}

Some activities in managing knowledge management are carried out by the HRM division in collaboration with production leaders. Ideally, according to one Human Resources staff, on the job training is carried out if the number of new employees is at least 20 people. Therefore, if they do not meet the quota, new employees wait until the number of employees is approximately 20 or they take on the job training independently with stages that have been arranged according to schedule.

From the results of interviews with the HRM Division, every new employee is required to attend the socialization with materials including; company regulations, corporate culture, organizational structure, job description, at that time they not only signed attendance but were given a discussion room and asked to provide a statement that they understood the content of the socialization. It is important to explain this so that new employees understand their roles, rights and obligations. Together, all employees build behavior to create a strong organizational culture. The activity was continued with mandatory training for 2 weeks where new employees received general knowledge related to the company's business and the $\mathrm{A}$ to $\mathrm{Z}$ production process of program development.

After participating in mandatory training, employees return to their actual jobs. They are placed in positions according to the agreement at the beginning of the work contract. They were given an explanation of the roles and responsibilities as well as the rules of do and don'ts 
as well as explained on the freedom to choose the work process. All aim to provide room for psychological well-being intervention. Then they continued with 2 weeks of training in class to learn the obstacles and barriers to System Operating Procedures between work units.

On the sidelines of on-the-job training activities, new and old employees hold meetings. In these meetings, new employees and old employees are informed about things that need to be improved so that their discussions with each other occur. The meeting is held every 2 weeks and is attended by all new employees and old employees according to their schedule and field and one of the Human Resources staff is an observer at the meeting.

In the fourth month, each employee is rotated to another division but is still within the scope of his division. For example, the production department has 6 areas, namely the talent artist, creative person, production assistant, cameraman, editor. they are assigned to the six sections of the field according to a predetermined schedule. In the fifth month they make a report and present what they have found and done for 5 months to their superiors and are observed by Human Resources staff. This result is also their assessment so far. In the sixth month the compilation of their reports becomes documentation and becomes a consideration for making better syllabus and methods. For 6 months, new members are monitored and given the opportunity to consider the appropriateness of their values with those of the company.

One important finding in the field shows that the Human Resources Management (HRM) Division neglects the structured documentation process. They don't seem to prioritize formally writing down and documenting all new employee input in detail. From interviews with the HRM Division that they have not documented the thought, crucial work processes into one permanent concept. But they immediately apply the things that are renewed through direct action. They feel that the examples of programs that have been produced can represent examples to be directly discussed into new knowledge. However, some integrated documentation related to the writing and video delivered in the electric-bulletin is not yet available in a structured manner and has not been broadcast and enjoyed by employees so that knowledge sharing cannot take place anytime and anywhere. Employees have not been able to access and read freely so that their knowledge can increase at any time.

\subsection{Discussion}

Knowledge is an important organizational asset. Knowledge in organizations is a core competency that shows the competitive value of the organization [9]. As organizational competitiveness is getting faster, managing knowledge is one of the strategies to achieve organizational performance. These efforts are made by fully utilizing information and data combined with all the skills, ideas, commitment and motivation of employees in an integrated manner into company investment. Knowledge Management in organizations supports organizational growth and development [10].

The activities of managing knowledge management developed by the HRM Division in collaboration with the Production division are carried out through several major activities, namely on the job training activities. On the Job training, training in which employees or prospective employees are placed in actual working conditions, under the guidance and supervision of experienced senior employees or a supervisor. The purpose of on the job training is to provide hands-on experience, especially for new employees in introducing the competencies needed to carry out work [11]. In these activities, employees can observe the work that is their responsibility and do the work repeatedly so that they are able to master the work and can explain and do their work themselves without supervisor guidance and in the end can increase their confidence. On the job training also has an effect on training costs incurred as 
well as more efficiency and faster knowledge transfer. The high voluntary turnover situation makes this activity an effective solution for this media company.

In on the job training, there are a series of activities, including socialization, namely activities to equip employees to internalize organizational values into their behavior to produce jobs [12]. Socialization and internalization activities can befoster a more professional working attitude because they have a comprehensive understanding of the culture, vision \& mission, and organizational values, equalize perceptions about the direction, goals and targets of the company in the future according to the company's vision and mission and increase leadership skills, a sense of belonging and a sense of responsibility responsible and foster harmony within the company by increasing a sense of togetherness and a positive mental attitude.

When employees carry out their roles at the beginning, they work to adjust the job description, but the leadership encourages they develop a learn and learn process so as to give birth to the development of new ideas quickly and generate new work experiences, and have an impact on the formation of employee fighting skills and ultimately increase job satisfaction. This activity is called job crafting where leaders can encourage to expand work tasks, both physically and cognitively. The experience of employees making updates when running new programs and changing programs every episode. Job crafting becomes an individual policy and focuses on changes in a positive direction and increases independence.

In job crafting activities, a new knowledge is obtained from the notes compiled by the field of development, the results of these notes are considered as training materials, both technical materials and soft skills. And the HRM Division can make training and development priority scales that are previously held and discussed with leaders in the production division. Apart from job crafting, the management of the HRM division and technical leaders designed a wellplanned job shadowing system. Job shadowing is mandatory for every new employee. After participating in this activity, they can stimulate the willingness and motivation of employees to increase their competence and the organization [13]. This activity accelerates new employees to know the organizational culture, work unit culture so as to strengthen knowing the production process they learn administrative processes.

The shadowing process makes them even more ready to do their job. Job shadowing makes employees get more and faster variations of knowledge and become familiar with several methods processes and work methods that have never been known before in his work [14]. It is widely recognized that job shadowing creates job involvement that has an impact on a positive state of mind marked by enthusiasm, dedication, and absorption. Schaufeli [15] improved in the work environment as it offers and introduces a fair number of new challenges and resources [16]-[19].

Several knowledge management activities in the production division unit show a transformation of knowledge routines in the organization where there is a transfer of tacit into explicit knowledge from organizational members to organizational members [20]. In addition, knowledge management in the production division is processed through the socialization process stages, mandatory training, job crafting and job shadowing, meeting activities. Meting activity is a knowledge sharing platform that contributes to the exchange of knowledge and experiences among employees [21]. Knowledge sharing can be defined as the process of sharing ideas, information, and tasks that are relevant to the task among team members [22].

All of these activities show that the HRM division is discovering, capturing, sharing and applying knowledge in order to increase knowledge to achieve organizational goals in a costeffective manner [23]. From several activities, it appears that the media company has built its assets by developing it and implementing competitive strategies that provide great benefits for knowledge in the company, even though in the event of high employee turnover voluntary The 
strategy carried out by the HRM media division is in line with Tung's strategy such as [24]. (1) keep knowledge from being lost in the event of a transition or resignation of an organization member; (2) minimizing the possibility of data loss; (3) identify critical areas of knowledge sources so that the company knows what the employee knows, even though the employee has left; and (4) developing tools and methods to capture and store knowledge. The application of knowledge management assists organizations in optimizing the intellectual assets of the organization with the aim of increasing employee competence, improving systems and procedures, and gathering knowledge from internal and external organizations, to become organizational intellectual property [25].

However, the fact in the findings is that there are limitations in storing knowledge that is easily accessible to every employee, such as the experience of senior employees in the ups and downs of creating systems. This limitation is because there is no special area that deals with knowledge management. At that time the KM area was combined with the training and system development area, even though this area became very important, especially since this media company had more than 1000 employees. The size of the business needs to be adjusted and aligned with business strategy, and the management of human resource system development, which includes designing the exchange of knowledge between employees as well as translating it into an information technology system so that it has an impact on increasing competence even though the company experiences employee changes [26].

In managing knowledge, organizations need a knowledge management information system (KMS) that provides features and tools for capturing, organizing and managing knowledge [27]. KMS is a knowledge-based information technology system to support knowledge creation, management and dissemination to employees within a company or organization [28]. Therefore the existence of KMS is encouraged through appropriate organizational policies (e.g. reward systems) and facilitated through appropriate organizational infrastructure (e.g. communication information systems) [29]. Efforts must be made and awareness created to ensure that employees understand the benefits of sharing knowledge [30].

From the knowledge management process which includes on the job training, socialization, job crafting, job shadowing, there is a strong growth in collective intelligence, even though the conditions in this company are marked by high voluntary turnover, which is known as continuous learning competence is getting better [31]. Continuous learning is a mentality and behavioral routine that reflects a belief and dedication to learning and change. Meanwhile according to [32] Organizational learning is considered as an organizational ability to create, acquire, interpret, transfer and share knowledge aimed at modifying behavior to describe new knowledge and insights.

\section{Conclusion}

The strategy to build knowledge management in Media Company is carried out through several activities, but the main activities are based on on the job training. On the job training activities that are believed to build knowledge management effectively and efficiently. On the one hand, it can integrate several KM activities, from discovering, capturing, sharing, and applying.

The collaboration between the HRM Division and the Production Division is also directed, there are many benefits gained from this collaboration, especially the increased competency of continuous learning and signature experiences for all employees in the company. The HRM 
division can improve the training module and the KM sharing system practically works well. However, the HRM division is expected to be able to develop and take full advantage of technology, have a work unit.

\section{References}

[1] V. Slavianska, "Measuring the Impact of Human Resource Management Practices on," Probl. Manag. 21st Century, 2012.

[2] M. Yasin, "Knowledge, Talent Management, Knowledge Management, and Lessons from Knowledge Enterprises," vol. 26, no. 1, pp. 1-14, 2021.

[3] V. Delshab, D. Y. Pyun, S. Kerwin, and J. G. Cegarra-Navarro, "The impact of unlearning context on organizational performance through knowledge management: A case of community sport clubs in Iran,” Sport Manag. Rev., 2020.

[4] J. W. Creswell, Qualitative inquiry and research design: Choosing among five traditions. 1998.

[5] I. McLafferty, "Focus group interviews as a data collecting strategy," Journal of Advanced Nursing. 2004.

[6] M. J. Kingry, L. B. Tiedje, and L. L. Friedman, "Focus groups: a research technique for nursing," Nurs. Res., vol. 39, no. 2, pp. 124-125, 1990.

[7] J. W. Creswell and V. L. P. Clark, "Designing and Conducting Mixed Methods Studies," in Workshop for the 2011 Society for Social Work and Research annual meeting, 2011.

[8] Z. T. Rony, Siap Fokus, Siap Menulis Skripsi, Tesis, Disertasi (Jurus Mudah Gunakan Metode Kualitatif Tipe Studi Kasus), First., no. August. Jakarta: Pusat Studi Sumber Daya Manusia (PSSDM), 2017.

[9] M. L. Liu, C. P. Lin, S. W. Joe, and K. J. Chen, "Modeling knowledge sharing and team performance: The interactions of ethical leadership and ambidexterity with politics and job complexity," Manag. Decis., 2019.

[10] F. A. Uriarte, "Introduction to Knowledge Management: A Brief Introduction to the Basic Elements of Knowledge Management for Non-practitioners Interested in Understanding the Subject," ASEAN Found., 2008.

[11] M. Tait, M. Y. Padgett, and T. T. Baldwin, "Job and Life Satisfaction: A Reevaluation of the Strength of the Relationship and Gender Effects as a Function of the Date of the Study," J. Appl. Psychol., 1989.

[12] G. R. Slemp and D. A. Vella-Brodrick, "Optimising Employee Mental Health: The Relationship Between Intrinsic Need Satisfaction, Job Crafting, and Employee Well-Being,” J. Happiness Stud., 2014.

[13] R. Bolton and J. Gold, "Career Management: Matching the Needs of Individuals with the Needs of Organizations," Pers. Rev., 1994.

[14] Z. T. Rony, F. M. Lubis, and A. Rizkyta, "Job shadowing as one of the effective activities in the promotion process creates quality managers,” Int. J. Recent Technol. Eng., 2019.

[15] W. Schaufeli, M. Salanova, V. González-romá, and A. Bakker, "The Measurement of Engagement and Burnout: A Two Sample Confirmatory Factor Analytic Approach,” J. Happiness Stud., 2002.

[16] A. B. Bakker, "An evidence-based model of work engagement," Current Directions in Psychological Science. 2011

[17] P. Brough et al., "Work-life balance: A longitudinal evaluation of a new measure across Australia and New Zealand workers," Int. J. Hum. Resour. Manag., 2014.

[18] J. R. B. Halbesleben, "A meta-analysis of work engagement: Relationships with burnout, demands, resources, and consequences," in Work Engagement: A Handbook of Essential Theory and Research, 2010.

[19] S. Mauno, U. Kinnunen, and M. Ruokolainen, "Job demands and resources as antecedents of work engagement: A longitudinal study,” J. Vocat. Behav., 2007. 
[20] N. Evans and M. Easterby-Smith, "Three Types of Organizational Knowledge: Implications for the Tacit-Explicit and Knowledge Creation Debates,” Fourth Int. Conf. Organ. Learn. Knowl. Manag., 2001.

[21] N. A. Ghani Al-Saffar and A. M. Obeidat, "The effect of total quality management practices on employee performance: The moderating role of knowledge sharing," Manag. Sci. Lett., vol. 10, no. 1, pp. 77-90, 2020.

[22] A. Srivastava, K. M. Bartol, and E. A. Locke, "EMPOWERING LEADERSHIP IN MANAGEMENT TEAMS: EFFECTS ON KNOWLEDGE SHARING, EFFICACY, AND PERFORMANCE,” Acad. Manag. J., vol. 49, no. 6, pp. 1239-1251, 2006.

[23] I. Becerra-Fernandez, A. J. Gonzalez, and R. Sabherwal, Knowledge management: challenges, solutions, and technologies, Volume 1. Pearson/Prentice Hall Upper Saddle River, NJ, 2004.

[24] K. Y. Tung, Memahami Knowledge Management, Cetakan I. Jakarta: PT. Indeks, 2018.

[25] Dunamis, Successful Implementation of KM in Indonesia. Jakarta: PT Dunamis Intra Sarana, 2013.

[26] A. Djeflat, "The Governance of Territorial Innovation Systems (TIS) and the Role of Intermediate Institutions in Maghreb Countries.," in Building Innovation Systems in Africa: Experiences from the Maghreb, A. Djeflat, Ed. France: Adonis \& Abbey, 2010, pp. 225-254.

[27] Y. Hwang, H. Lin, and D. Shin, "Knowledge system commitment and knowledge sharing intention: The role of personal information management motivation,” Int. J. Inf. Manage., 2018.

[28] B. A. Andhara, F. R. Umaro, and C. H. T. Lubis, Knowledge Management - Strategi Mengelola Pengetahuan agar Unggul di Era Disrupsi, Edisi I. Jakarta: PT. Gramedia Pustaka Utama, 2018.

[29] T. H. Kuo, "How expected benefit and trust influence knowledge sharing," Ind. Manag. Data Syst., vol. 113 , no. 4, pp. 506-522, 2013.

[30] K. K. Jain, M. Sandhu, and G. Sidhu, "Knowledge sharing among academic staff: a case study of business schools in Klang Valley, Malaysia," J. Adv. Sci. Arts, vol. 2, no. September 2015, pp. 23 29, 2007.

[31] Z. T. Rony, M. Yasin, F. M. Lubis, and F. Syarief, "The Role of Active Constructive Feedback in Building Employee Performance (Case study at a private construction company in Indonesia 20182019),”Int. J. Psychosoc. Rehabilation, vol. 24, no. 08, pp. 9350-9359, 2020.

[32] C. Harris and O. Gokcekus, "Learning in Action: A Guide to Putting the Learning Organization to Work.," Acad. Manag. Perspect., 2000. 